\title{
KELEMBAGAAN KEMITRAAN PENGELOLAAN HUTAN RAKYAT DI PROVINSI JAWA BARAT
}

\author{
(Institutional Partnership of Private Forest Management in West Java Province) \\ Edi Kurniadi ${ }^{1 *}$, Hardjanto ${ }^{2}$, Bramasto Nugroho ${ }^{2}$, Sumardjo ${ }^{3}$ \\ ${ }^{1}$ Sekolah Pascasarjana, Institut Pertanian Bogor \\ Kampus IPB Dramaga, Bogor 16680 \\ ${ }^{2}$ Departemen Manajemen Hutan, Institut Pertanian Bogor \\ Kampus IPB Dramaga, Bogor 16680 \\ ${ }^{3}$ Departemen Sain Komunikasi dan Pengembangan Masyarakat \\ Institut Pertanian Bogor, Kampus IPB Dramaga, Bogor 16680 \\ Naskah masuk : 26 Pebruari 2013; Naskah diterima : 24 Juni 2013
}

\begin{abstract}
Partnership of private owned forest management is an effort to improve the welfare of farmers. Questions to be answered in this study is how the performance of the institutional partnership between farmers and partners. The study was aimed at analysing the performance of institutional partnership between farmers and three different partners, namely small industry, large industries and non-industrial businesses. The research was conducted in JulyOctober 2012 in Garut, Tasikmalaya, and Ciamis Districts. The study found that the partner's approach to farmers influence the implementation of the partnership. Relationships between partners and farmers as well as the enforcement of the agreement affect the performance of the partnership agreement. The proportion o finput-output sharing affects the financial viability of the partnership. Agency costs may affect the principal-agent relationship. There are some findings that need to be considered in the partnership program, that is: preparing farmers as partnership candidate, and approach of the company as potential partners.
\end{abstract}

\section{Keywords: Institution, partnerships, private forest management, financial viability}

\begin{abstract}
ABSTRAK
Kemitraaan pengelolaan hutan rakyat merupakan salah satu upaya untuk meningkatkan kesejahteraan petani hutan rakyat. Pertanyaan yang ingin dijawab dalam penelitian ini adalah bagaimana kinerja kelembagaan kemitraan antara petani dengan mitra. Penelitian ini bertujuan untuk menganalisis kinerja kelembagaan kemitraan antara petani dengan tiga mitra yang berbeda yaitu industri kecil, industri besar, serta non industri. Penelitian dilaksanakan pada bulan Juli - Oktober 2012 di Kabupaten Garut, Tasikmalaya, dan Ciamis. Penelitian ini menemukan bahwa kinerja kemitraan pengelolaan hutan rakyat di lokasi studi cukup beragam yang dipengaruhi oleh hubungan sosial para pihak, kepatuhan terhadap kesepakatan perjanjian, pengawasan dan sanksi pelanggaran kesepakatan, serta proporsi sharing input-output. Proporsi sharing input-output berpengaruh terhadap kelayakan finansial kemitraan. Biaya keagenan dapat mempengaruhi hubungan principal-agent. Terdapat beberapa temuan yang perlu dipertimbangkan dalam melakukan program kemitraan, yaitu: penyiapan petani calon peserta kemitraan, dan pendekatan kepada pengusaha sebagai calon mitra.
\end{abstract}

\section{Kata kunci : Kelembagaan, kemitraan, pengelolaan hutan rakyat, kelayakan finansial}

\section{PENDAHULUAN}

Luas hutan rakyat mengalami kenaikan dari tahun 2003 seluas 1,6 juta ha (Dephut dan BPS, 2004) menjadi seluas 1,9 juta ha pada tahun 2008 (Ditjen BPK, 2009). Peranan hutan rakyat dalam mendukung bahan baku industri primer dan menurunkan lahan kritis secara nasional cukup signifikan. Oleh karena itu, peningkatan luas hutan rakyat yang mandiri merupakan salah satu sasa- ran pokok dari arah pembangunan jangka panjang kehutanan tahun 2006-2025 (Dephut, 2006). Pengelolaan hutan rakyat yang terjadi sampai saat ini sebagian besar masih belum dapat meningkatkan kesejahteraan masyarakat (Hardjanto, 2001). Hal ini disebabkan karena praktek-praktek pengelolaan hutan rakyat yang masih tradisional dan bersifat subsisten. Dengan adanya kemitraan diharapkan akan terjadi pergeseran paradigma petani ke arah pengelolaan yang bersifat modern dan komersial. 
Terdapat beberapa tipologi kemitraan antara perusahaan dan masyarakat, diantaranya adalah kerjasama antara industri pengolahan kayu dengan kelompok tani dalam hal kesepakatan pasokan bahan baku dengan cara bagi hasil (Mayers, 2000). Kemitraan antara masyarakat dengan perusahaan bidang kehutanan di Indonesia dimulai sejak pemerintah mengeluarkan kebijakan pembinaan masyarakat desa hutan (PMDH) tahun 1991 melalui Keputusan Menteri Kehutanan Nomor 691 Tahun 1991, yang bertujuan untuk mengurangi konflik antara masyarakat dengan pemegang konsesi hutan, dan untuk mendorong pembinaan masyarakat desa hutan. Sementara kemitraan di pulau Jawa terjadi antara perusahaan dengan petani dalam rangka pemenuhan bahan baku industri (Prihadi et al., 2010). Selain itu, kemitraan pengelolaan hutan rakyat juga terjadi antara petani dengan pengusaha non industri, berupa penanaman pohon untuk dijual ke industri pengolahan kayu dengan bentuk bagi hasil.

Beberapa penelitian menunjukkan keberhasilan kemitraan antara petani dengan perusahaan, diantaranya karena kedua pihak dapat merancang dan melaksanakan kemitraan yang saling menguntungkan (Key dan Runsten 1999, Prihadi et al., 2010), petani yang bermitra mempunyai pendapatan lebih daripada yang tidak bermitra (Miyata et al., 2009), mitra memberikan kredit kepada petani dan terjadi hubungan bahu membahu (interlock transaction) (Smith et al., 1999). Namun demikian, masih terdapat beberapa permasalahan yang dihadapi petani dalam melaksanakan ke- mitraanya itu kurangnya mekanisme untuk membangun kepercayaan, tidak mempunyai strategi jangka panjang yang jelas (Nawir dan Santoso, 2005), petani kurang memiliki pengetahuan tentang harga pasar, akses terhadap pasar yang lemah, tidak mampu bernegosiasi (Race et al., 2009). Untuk itu perlu tercipta keseimbangan antara petani dengan mitra sehingga kemitraan menguntungkan kedua pihak. Penelitian ini penting karena menghasilkan strategi untuk mempersiapkan petani dalam kemitraan.

Penelitian ini bertujuan untuk menganalisis kelembagaan kemitraan pengelolaan hutan rakyat. Secara khusus menguraikan karakteristik kemitraan pengelolaan hutan rakyat antara petani dan mitranya, menganalisis potensi hasil hutan dari kemitraan, menerangkan alur transaksi input-output kemitraan, menganalisis kelayakan kemitraan dari ketiga pola kemitraan, serta menganalisis kinerja kemitraan pengelolaan hutan rakyat.

\section{METODE PENELITIAN}

\section{A. Tempat dan Waktu}

Pemilihan lokasi penelitian ditentukan dengan beberapa pertimbangan, antara lain: (1) terdapat petani hutan rakyat yang terlibat kemitraan dengan industri primer kayu rakyat maupun non industri; (2) terdapat keragaman pola kemitraan; dan (3) kemitraan yang terjadi pada tahap daur

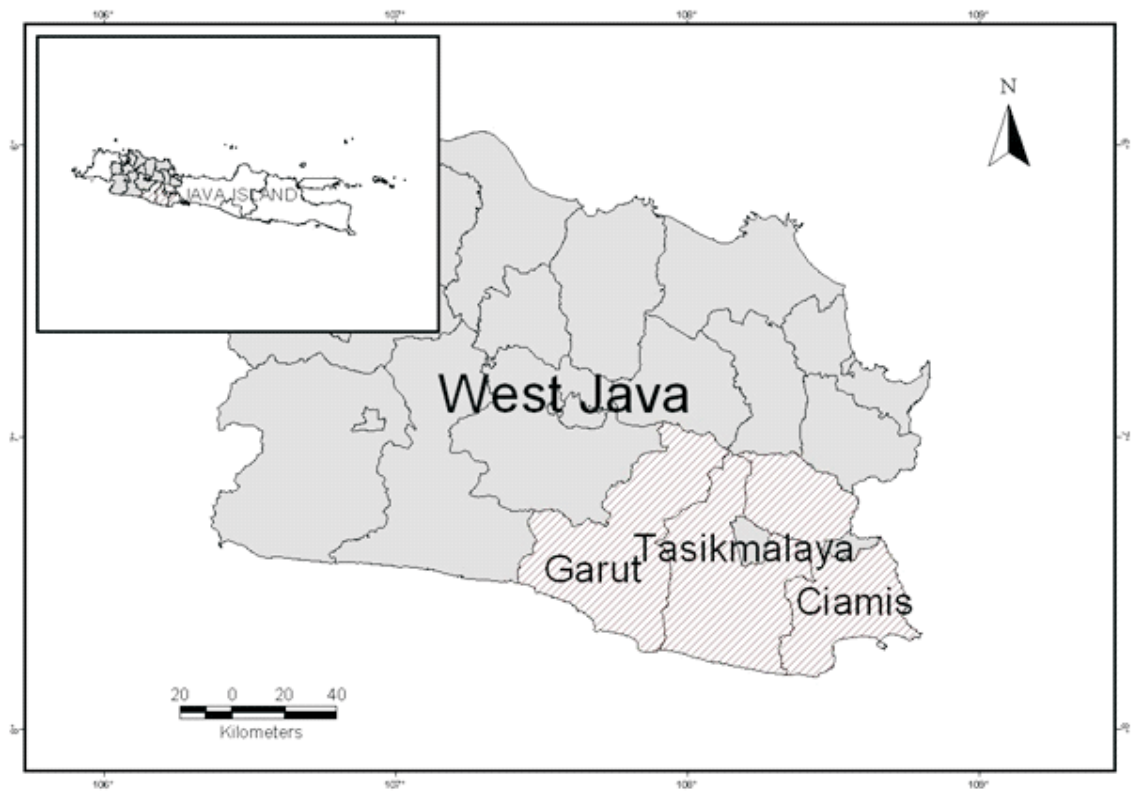

Gambar(Figure) 1. Lokasi penelitian kemitraan pengelolaan hutan rakyat (Partnership of private forest management study site) 
panen pertama. Berdasarkan pertimbangan tersebut, maka lokasi penelitian yang dipilih adalah: (1) Kabupaten Garut (Kecamatan Banjarwangi), kemitraan antara petani dengan industri kecil berupa industri penggergajian (PD. Sumber Hasil); (2) Kabupaten Tasikmalaya (Kecamatan Tanjungjaya), kemitraan antara petani dengan industri besar berupa industri pengolahan kayu (PT Bina Inti Lestari-BIL yang merupakan anak perusahaan PT. Bina Kayu Lestari (BKL) group); (3) Kabupaten Ciamis (Kecamatan Panawangan), kemitraan penanaman antara petani dengan pengusaha non industri yaitu Gabungan Kelompok Tani (Gapoktan) Anugerah Alam Subur. Gambar 1 menunjukkan lokasi penelitian di 3 kabupaten di Jawa Barat.

Penelitian dilaksanakan pada bulan Juli 2012 sampai dengan Oktober 2012. Bahan yang digunakan dalam penelitian ini adalah dokumen perjanjian kerjasama pengelolaan hutan rakyat. Alat yang digunakan adalah kuesioner, dan alat untuk kegiatan inventarisasi pohon (pita meter, tally sheet), alat tulis, kamera, dan alat perekam.

\section{B. Pengumpulan Data}

Penelitian melibatkan 181 petani contoh peserta kemitraan yang dipilih secara acak klaster (clusterrandom sampling) didasarkan kepada perbedaan pola kemitraan (Purwanto dan Sulistyastuti 2011), Penentuan jumlah mengikuti formula dari Krejcie dan Morgan (1970) sebagai berikut:

$$
S=\frac{X^{2} N P(1-P)}{d^{2}(N-1)+X^{2} P(1-P)}
$$

Keterangan:

$\mathrm{S}=$ jumlah sampel

$\mathrm{N}=$ jumlah populasi

$\mathrm{P}=$ proporsi populasi $=0,5$

$\mathrm{d}=$ derajat kesalahan $(0,05)$

$\mathrm{X}^{2}=$ nilai tabel $\mathrm{X}^{2}(3,84)$, berasal dari nilai confidence interval $95 \%(1,96)$

Kuesioner merupakan instrumen penelitian yang digunakan untuk mengumpulkan data dari para petani responden. Selain itu dilakukan juga wawancara mendalam (indepth interview) kepada ketua kelompok tani, pengusaha (mitra), pedagang pengumpul, kepala desa, penyuluh kehutanan, petugas dan pejabat dinas kabupaten yang menangani kehutanan. Penelaahan dokumen kontrak dilakukan untuk mengetahui kesepakatan kerjasama antara petani dan mitra atau perusahaan.Pengukuran diameter pohon bertujuan untuk mengetahui potensi kayu hasil kemitraan, yang dilakukan pada petak ukur $20 \mathrm{~m}$ x 20m di setiap lahan garapan responden.

\section{Analisis Data}

Teknik analisis data yang digunakan dalam penelitian ini adalah teknik analisis deskriptif dan analisis finansial. Analisis deskriptif dan tabulasi digunakan untuk menganalisis karakteristik kemitraan pengelolaan hutan rakyat, potensi hasil hutan rakyat dari kemitraan, alur transaksi inputoutput kemitraan, serta kinerja kelembagaan kemitraan. Analisis finansial digunakan untuk mengetahui kelayakan usaha kemitraan (Gittinger, 1982), dengan kriteria NPV $>0, \mathrm{BCR}>1$, dan IRR $>$ Suku bunga bank. Suku bunga yang digunakan dalam analisis finansial sebesar 13\% yaitu suku bunga pada tahun 2012.

\section{HASIL DAN PEMBAHASAN}

\section{A. Perjanjian Kerjasama}

Kemitraan pengelolaan hutan rakyat di Kabupaten Garut dan Tasikmalaya antara kelompok tani dengan mitranya, yaitu PD. Sumber Hasil dan PT. Bin Inti Lestari, dibuktikan dengan perjanjian kerjasama melalui akte notaris. Kemitraan tersebut dalam rangka pelaksanaan program pembangunan model hutan rakyat kemitraan dari Balai Pengelolaan Daerah Aliran Sungai (BPDAS) Cimanuk-Citanduy yang dimulai pada tahun 2008. Waktu perjanjian selama satu kali panen (5 tahun) pohon Albasia (Falcataria moluccana (Miq.) Barneby \& J.W. Grimes), dan dapat diperpanjang kembali sesuai dengan kesepakatan kedua belah pihak. Lingkup kerjasama dalam pengolahan tanah dan persiapan lahan, penanaman, pemeliharaan/perawatan, penjagaan keamanan sampai pemanenan tanaman Albasia serta pemasaran. Hak dan kewajiban kedua pihak pada kemitraan di Kabupaten Garut dan Tasikmalaya pada Tabel 1 .

Kemitraan pengelolaan hutan rakyat di Kabupaten Ciamis dilakukan melalui surat perjanjian kerjasama bagi hasil dalam penanaman pohon jabon (Anthocepalus cadamba Miq.), yang dimulai pada musim tanam tahun 2010. Perjanjian dilakukan antara pemimpin Gapoktan atas nama pribadi dengan setiap petani peserta kerjasama yang ditandatangan di atas materai dan disaksikan oleh ahli waris kedua belah pihak. Hak dan kewajiban kedua pihak pada kemitraan di Kabupaten Ciamis disajikan pada Tabel 2.

Persentase bagi hasil kayu dari kemitraan antara petani dan mitra setiap lokasi penelitian 
Tabel(Table) 1. Hak dan kewajiban para pihak pada perjanjian kerjasama di kabupaten Garut dan Tasikmalaya (The rights and responsibility that the parties bear in the agreement for the regencies of Garut and Tasikmalaya)

\begin{tabular}{|c|c|c|}
\hline & Hak (Rights) & Kewajiban (Responsibility) \\
\hline $\begin{array}{l}\text { Mitra } \\
\text { (Partner) }\end{array}$ & $\begin{array}{l}\text { 1. Memperoleh bagi hasil } \\
\text { dari tanaman Albasia } \\
\text { (Gaining a share from the } \\
\text { Albasia harvest) } \\
\text { 2. Mendapat jaminan } \\
\text { keamanan tanaman yang } \\
\text { dikerjasamakan(Gaining } \\
\text { guaranty of the security of } \\
\text { the plants managed in the } \\
\text { partnership) }\end{array}$ & $\begin{array}{l}\text { 1. Menyediakan bibit tanaman hutan dengan menggunakan } \\
\text { bibit yang berkualitas } \\
\text { (Providing high quality seedlings for the forest) } \\
\text { 2. Menanggung biaya ongkos kirim bibit sampai ke lokasi } \\
\text { (Responsible for transporting cost to the location) } \\
\text { 3. Mengorganisasikan masyarakat yang akan menggarap } \\
\text { lahan (Organizing the community members who will } \\
\text { cultivate the land/area) } \\
\text { 4. Memberikan bimbingan teknis kepada petani peserta } \\
\text { (Providing technical guidance for the participating farmers) } \\
\text { 5. Melaksanakan pengawasan dan pemantauan kepada } \\
\text { petani peserta (Supervising and monitoring the } \\
\text { participating farmers) } \\
\text { 6. Menampung dan memasarkan hasil produksi tanaman } \\
\text { Albasia dalam bentuk gelondongan (Collecting and } \\
\text { marketing the harvest of Albasia wood in the form of logs) } \\
\text { 7. Menanggung } 50 \% \text { biaya pemanenan *(khusus untuk di } \\
\text { Kabupaten Tasikmalaya) } \\
\text { (Responsible for } 50 \% \text { of the cost of harvesting) }\end{array}$ \\
\hline $\begin{array}{l}\text { Petani } \\
\text { (Farmer) }\end{array}$ & $\begin{array}{l}\text { 1. Memperoleh bagi hasil } \\
\text { dari tanaman } \\
\text { Albasia (Gaining a share } \\
\text { from the Albasia harvest) } \\
\text { 2. Mendapatkan jaminan } \\
\text { pasar dan jaminan harga } \\
\text { yang wajar dari mitra } \\
\text { (Gaining guaranty of } \\
\text { market and proper price } \\
\text { from the partner ) }\end{array}$ & $\begin{array}{l}\text { 1. Menyediakan pupuk tanaman untuk digunakan pada } \\
\text { tanaman hutan yang dikerjasamakan } \\
\text { (Providing fertilizer to be used for the forest managed in } \\
\text { the partnership) } \\
\text { 2. Mengambil bibit tanaman dari tempat penampungan ke } \\
\text { lokasi penanaman (Taking the seed lings from the collection } \\
\text { center to the location of the planting) } \\
\text { 3. Melaksanakan persiapan lahan } \\
\text { (Implementing land preparation) } \\
\text { 4. Menanam dan memelihara tanaman termasuk } \\
\text { memberikan pupuk tanaman (Planting and maintaining } \\
\text { the trees as well giving the fertilizer) } \\
\text { 5. Merawat dan menjaga keberhasilan dan keamanan } \\
\text { tanaman sampai waktu panen (Maintaining and securing } \\
\text { the plants until the period of harvesting) } \\
\text { 6. Menanggung } 50 \% \text { biaya pemanenan *(khusus untuk di } \\
\text { Kabupaten Tasikmalaya) } \\
\text { (Responsible for } 50 \% \text { of the cost of harvesting*) }\end{array}$ \\
\hline
\end{tabular}

Keterangan(Remarks) : * Biaya panen di Kabupaten Tasikmalaya dibebankan kepada kedua belahpihak, sedangkan di Garut di bebankan kepada petani (The cost of harvesting in the Regency of Tasikmalaya is the responsibility of both parties, whereas in Garut, the cost of harvesting isof farmer responsibility)

bervariasi mulai dari $40-60 \%$ untuk petani dan $15-60 \%$ untukmitra (Tabel 3).

Dilihat dari bentuk perjanjian kesepakatan, kemitraan di Kabupaten Garut dan Tasikmalaya lebih mengikat terhadap kedua belah pihak dibandingkan dengan perjanjian kerjasama di Kabupaten Ciamis. Dilihat dari isi, perjanjian kerja- sama di Kabupaten Garut dan Tasikmalaya lebih rinci daripada Ciamis. Namun demikian, petani di Garut dan Tasikmalaya sebagian besar (65\%) tidak memahami isi perjanjian, bahkan sebesar $62 \%$ tidak memahami apa saja hak dan sebesar $44 \%$ tidak memahami kewajiban dalam kerjasama tersebut. Petani hanya memahami bahwa de- 
Tabel(Table) 2. Hak dan kewajiban para pihak pada perjanjian kerjasama di Kabupaten Ciamis (The rights and responsibility that the parties bear in the agreement for the regency of Ciamis)

\begin{tabular}{|c|c|c|}
\hline & Hak (Rights) & Kewajiban (Responsibility) \\
\hline Mitra & $\begin{array}{l}\text { 1. Memperoleh bagi hasil dari } \\
\text { tanaman Jabon } \\
\text { (Gaining a share from the } \\
\text { profit of Jabon trees) } \\
\text { 2. Mendapat jaminan keamanan } \\
\text { tanaman yang } \\
\text { dikerjasamakan } \\
\text { (Gaining guaranty of security } \\
\text { of the plants/trees managed } \\
\text { in the partnership) }\end{array}$ & $\begin{array}{l}\text { 1. Menyediakan bibit pohon (Providing the seedlings) } \\
\text { 2. Menanggung biaya pembersihan } \\
\text { (Responsible for the cost of cleaning) } \\
\text { 3. Menanggung biaya penanaman } \\
\text { (Responsible for the cost of planting) } \\
\text { 4. Menanggung biaya pemupukan dan pemeliharaan } \\
\text { sampai siap untuk dipanen (Responsbile for the cost of } \\
\text { fertilizing until the time for harvesting) }\end{array}$ \\
\hline Petani & $\begin{array}{l}\text { 1. Memperoleh bagi hasil dari } \\
\text { tanaman Jabon } \\
\text { (Gaining a share from the } \\
\text { profit of Jabon trees) } \\
\text { 2. Mendapatkan jaminan pasar } \\
\text { dan jaminan harga yang wajar } \\
\text { dari mitra } \\
\text { (Gaining guaranty of market and } \\
\text { proper price from the partner) }\end{array}$ & $\begin{array}{l}\text { 1. Menyediakan lahan sesuai dengan surat tanah untuk } \\
\text { penanaman jabon (Providing land according to the } \\
\text { certificate that is for the planting of Jabon trees) } \\
\text { 2. Mengerjakan/menggarap sendiri tanaman tumpangsari } \\
\text { apabila ditanami tanaman tumpangsari } \\
\text { (Managing the intercropping plants on their own if they } \\
\text { themselves want to provide the plants) } \\
\text { 3. Tidak menjual atau menyewakan lahan ke pihak lain } \\
\text { (Not selling or leasing the land to any other parties) }\end{array}$ \\
\hline
\end{tabular}

Tabel(Table) 3. Bagi hasil kemitraan pengelolaan hutan rakyat di lokasi studi (Profit-sharing on partnerships of private owned Bforest management in study area)

\begin{tabular}{lccccc}
\hline & \multicolumn{5}{c}{ Persentase (percentage) } \\
\cline { 2 - 6 } Kabupaten (Districts) & $\begin{array}{c}\text { Petani } \\
\text { (Farmer) }\end{array}$ & $\begin{array}{c}\text { Mitra } \\
\text { (Partner) }\end{array}$ & $\begin{array}{c}\text { Kas kelompok } \\
\text { (Farmer group's } \\
\text { account })\end{array}$ & $\begin{array}{c}\text { Kas desa } \\
\text { (Village's } \\
\text { account) }\end{array}$ & Zakat \\
\hline Garut & 60 & 30 & 7,5 & 2.5 & 0 \\
Tasikmalaya & 75 & 15 & 7,5 & 2,5 & 0 \\
Ciamis* & 40 & 60 & 0 & 2,5 & 2,5 \\
\hline
\end{tabular}

Keterangan (remarks): *Sumbangan kas desa dan zakat dihitung sebelum pembagian laba (donation for village's account and zakat calculated beforeprofit distribution)

ngan perjanjian tersebut mereka akan mendapatkan bantuan bibit dan pupuk serta mereka harus menjualnya ke mitra. Hal ini disebabkan karena perjanjian kerjasama hanya ditandatangani oleh ketua kelompok sedangkan anggota kelompok tidak banyak terlibat, sebagaimana ditemukan juga oleh Nawir dan Santoso (2005) yang menyatakan bahwa petani tidak peduli dengan haknya karena pengusaha hanya melakukan kesepakatan melalui ketua kelompok. Selanjutnya, Frankel et al. (1996) menyampaikan bahwa perjanjian kesepakatan tidak dilihat apakah perjanjian tersebut formal atau tidak, yang penting perjanjian tersebut berimplikasi terhadap jalannya kemitraan, tercipta kepercayaan para pihak, dan loyalitas terhadap kesepakatan sehingga menjadikan penguatan terhadap kemitraan.

Perjanjian kerjasama tersebut menunjukkan ketidakseimbangan antara hak dan kewajiban masing-masing pihak. Kewajiban lebih banyak daripada hak. Ketidakseimbangan juga terjadi pada pembagian hasil di Kabupaten Tasikmalaya. Pihak mitra sebagai principal dibebani untuk menanggung setengah dari biaya pemanenan, sedangkan proporsi pembagian hasil hanya mendapatkan $15 \%$. Sementara principal di Kabupaten Garut medapatkan proporsi pembagian hasil sebesar 30\% dan tidak ada tanggungan biaya panen. Ketidakseimbangan antara biaya dan manfaat yang mungkin didapatkan sebagai akibat dari 
perjanjian kesepakatan dapat menyebabkan disinsentif bagi masing-masing pihak, serta berpotensi terjadinya perilaku melakukan ingkar janji (moral hazard) terhadap kewajiban-kewajiban yang tercantum dalam perjanjian.

\section{B. Potensi Kayu Hasil Kemitraan Pengelola- an Hutan Rakyat}

Penanaman Albasia di Kabupaten Garut dan Tasikmalaya dilakukan baik secara monokultur maupun secara tumpangsari dengan tanaman bawah (kapolaga, cabe keriting, singkong, dan teh). Sementara di Kabupaten Ciamis, sebagian besar petani menanam jabon pada lahan yang sudah ada tanaman lain baik kayu-kayuan seperti albasia, mindi, suren, maupun tanaman setahun, antara lain pisang, ketela pohon, cabe rawit.

Hasil inventarisasi terhadap tanaman di tiga lokasi (Tabel 4) menunjukkan potensi tanaman Albasia di kabupaten Garut dan Tasikmalaya sangat rendah. Ketentuan teknis yang tercantum dalam perjanjian kerjasama menyatakan bahwa penebangan Albasia dilakukan pada pohon dengan keliling di atas $60 \mathrm{~cm}$ atau diameter sekitar $20 \mathrm{~cm}$.

Rendahnya potensi kayu di Kabupaten Garut dan Kabupaten Tasikmalaya kemungkinan karena serangan hama dan penyakit yang berkali-kali pada dua tahun pertama. Selain itu, petani di kabupaten Tasikmalaya mendapatkan bibit pada musim kemarau dengan kualitas yang rendah. Penyebab lainnya adalah pemeliharaan tanaman dilakukan secara konvensional, tidak ada perlakuan yang sesuai dengan kaidah silvikultur Albasia.

Hasil penelitian menunjukkan adanya masalah principal-agent dalam hal penyulaman dan pemeliharaan tanaman, yaitu masalah peminda- han hak kepemilikan (transfer of rights) dari bibit tanaman. Petani berpendapat bahwa bibit yang ditanam pada lahan hutan rakyat kemitraan adalah kepunyaan mitra. Petani tidak melakukan penyulaman karena hawatir sulaman tersebut dianggap sebagai tanaman dari perusahaan yang saat panen harus berbagi dengan mitra. Petani hanya membiarkan tanaman yang ada hidup apa adanya sampai menunggu masa kontrak habis (selama 5 tahun). Perlakuan petani terhadap tanaman kemitraan cenderung berbeda daripada terhadap tanaman tanpa kemitraan (mandiri).

Rerata diameter jabon di lokasi penelitian yang berumur 2 tahun adalah $4.13 \mathrm{~cm}$, masih lebih besar daripada rerata diameter Albasia yang hampir 5 tahun. Hal ini dapat dimengerti karena beberapa alasan: (1) jabon ditanam di lahan yang subur karena berupa kebun yang sudah ada tanaman lain sedangkan Albasia ditanam di lahan kritis; (2) sebagian tanaman jabon dipelihara dengan baik, serta karakteristikpertumbuhan jabon yang cepat (Orwa et al., 2009).

Pertumbuhan jabon hasil kemitraan dalam kisaran normal. Krisnawati et al. (2011) menyampaikan bahwa tegakan jabon yang berumur hingga 5 tahun mempunyai riap diameter tahunan $1,2-11,6 \mathrm{~cm}$ dan riap tinggi tahunan $0,8-7,9$. Hal ini dapat dipahami karena mitra mengupa-yakan agar keberhasilan tanaman tinggi karena mitra telah menginvestasikan modal yang cukup besar. Demikian pula dengan petani yang merasa tergiur dengan penghasilan yang dijanjikan apa-bila panen. Akan tetapi, tidak semua petani melakukan pemeliharaan. Beberapa alasan petani antara lain masih meragukan dengan pemasaran kayu jabon karena belum ada contoh pemasarannya, tidak mempunyai uang untuk pemeliharaan, dan sibuk dengan kegiatan atau pekerjaan lain.

Tabel(Table) 4. Potensi kayu hasil kemitraan pengelolaan hutan rakyat (Potential wood from partnerships of private owned forest management)

\begin{tabular}{|c|c|c|c|c|c|}
\hline No & Kabupaten (District) & $\begin{array}{l}\text { Umur tanaman } \\
\qquad \begin{array}{l}\text { (Age) } \\
\text { (tahun/ } \\
\text { year) }\end{array}\end{array}$ & $\begin{array}{l}\text { Jumlah bibit } \\
\text { ditanam } \\
\text { per ha (Number } \\
\text { of seedling } \\
\text { planted) }\end{array}$ & $\begin{array}{c}\text { Jumlah } \\
\text { pohon } \\
\text { hidup } \\
\text { per ha } \\
\text { (Number of trees } \\
\text { life) }\end{array}$ & $\begin{array}{l}\text { Rerata diameter } \\
\text { (Diameter } \\
\text { average) } \\
(\mathrm{cm})\end{array}$ \\
\hline 1. & Garut & 4 & 400 & 261 & 4,01 \\
\hline 2. & Tasikmalaya & 4 & 400 & 142 & 3,88 \\
\hline 3. & Ciamis & 2 & 833 & 542 & 4,13 \\
\hline
\end{tabular}




\section{Alur Transaksi Input-Output}

Ketiga lokasi penelitian mempunyai karakteristiknalur transaksi input-output yang berbeda dan dapat memengaruhi hubungan kemitraan antara petani dan mitra. Alur transaksi input-output dapat dilihat pada Gambar 2.

Pada kemitraan di Kabupaten Garut, mitra usaha memberikan input berupa bantuan bibit, pupuk, dan insektisida kepada petani secara langsung, tidak melalui perantara. Sedangkan mitra akan mendapatkan output berupa kayu dari petani dalam dua cara, yaitu langsung dijual ke mitra atau melalui perantara yaitu pedagang pengumpul. Dalam hal kayu dijual ke pedagang pengumpul, kesepakatan harga dan volume kayu yang dijual atas sepengetahuan dari mitra. Dalam hal ini fungsi pedagang pengumpul adalah sebagai tenaga upah. Hubungan transaksi input-output tersebut memungkinkan keeratan emosional antara kedua belah pihak. Mitra dapat memantau kondisi petani baik secara langsung maupun tidak langsung, sehingga dapat meminimalisasi masalah moral hazard yang mungkin dilakukan oleh petani. Apabila terjadi moral hazard yang dilakukan oleh petani, mitra memberikan teguran dan menanyakan alasan menjual kepada pihak lain. Sanksi diberikan kepada petani yang ingkar janji biasanya dengan tidak lagi memberikan bantuan yang diperlukan petani, baik bantuan pemberian sarana produksi maupun bantuan pinjaman dana untuk keperluan lain.

Alur transaksi input-output kemitraan di Kabupaten Tasikmalaya terlihat lebih panjang. Mitra usaha memberikan input kepada petani secara tidak langsung melalui pesantren Cintawana sebagai pendamping (Achmad et al., 2010). Demikian pula mitra mendapatkan output dari petani secara tidak langsung, melalui beberapa tingkat yaitu pedagang pengumpul, industri penggergajian, lembaga perantara, terakhir industri pengolahan kayu sebagai mitra. Rantai tataniaga kayu rakyat tersebut sejalan dengan temuan Effendi (2008) di Jawa Bagian Barat dan Hakim et al. (2009) di Jawa Tengah.

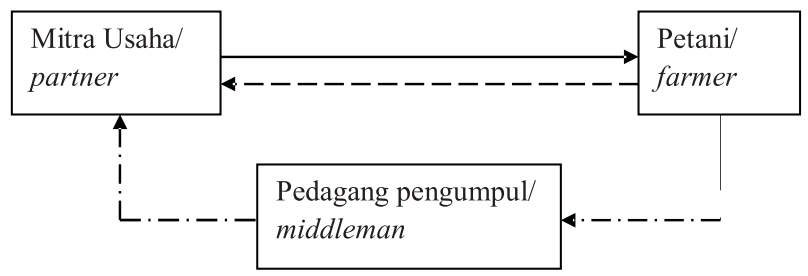

a. Kabupaten Garut/ Regenciyof Garut

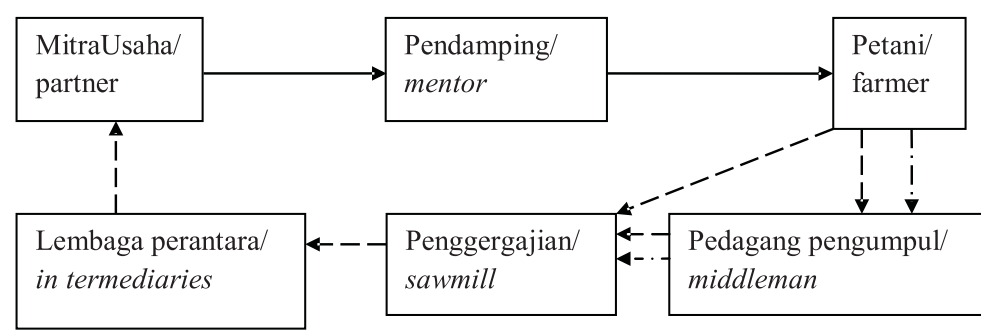

b. Kabupaten Tasikmalaya/ Regency of Tasikmalaya

\begin{tabular}{|l|l|l|}
\hline $\begin{array}{l}\text { Mitra Usaha/ } \\
\text { partner }\end{array}$ & \multicolumn{2}{l}{$\begin{array}{l}\text { Petani/ } \\
\text { farmer }\end{array}$} \\
\cline { 2 - 3 }
\end{tabular}

c. Kabupaten Ciamis (Regency of Ciamis)

$$
\begin{aligned}
\text { Keterangan: } & \longrightarrow \text { alur input (input flow) } \\
& \longrightarrow \text { alur output langsung (direct output flow) } \\
& \rightarrow \text { alur output tidak langsung (indirect output flow) }
\end{aligned}
$$

Gambar(Figure) 2. Alur transaksi input-output kemitraan hutan rakyat (Input-output transactionflow on partnership of private owned forest management) 
Memperhatikan hubungan antara mitra (PT. BIL) dan petani yang rentang kendalinya cukup panjang, memerlukan biaya transaksi yang cukup tinggi untuk menjamin kedua belah pihak dapat menjalankan kesepakatan (Key and Runsten, 1999). Selain itu, karena kedua pihak tidak berhubungan secara langsung, berpotensi untuk melakukan moral hazard. Perilaku moral hazard tersebut antara lain dengan tidak melakukan sebagian kewajiban penyulaman dan pemeliharaan, pembagian pupuk dan insektisida yang tidak merata, pengiriman bibit yang dikirim tidak sesuai harapan. Perilaku demikian ditemukan juga pada kemitraan di Kabupaten Bulukumba (Kusumedi dan Nawir, 2010). Perilaku moral hazard terjadi pada penjualan kayu dimana petani tidak menjual seluruh kayu kepada industri penggergajian binaan mitra.

Selain moral hazard dan transfer of rights, masalah penegakan pelanggaran kesepakatan terjadi pada kemitraan di Kabupaten Tasikmalaya. Pihak mitra tidak memberikan teguran terhadap sikap petani yang menterlantarkan tanaman, walaupun mitra mempekerjakan tenaga pengawas lapangan untuk memantau keadaan dan potensi di tingkat petani. Demikian pula petani tidak meminta pertanggungjawaban mitra terhadap penanaman. Selain itu, mitra tidak melakukan teguran atau sanksi terhadap petani yang menjual kayu ke pihak lain. Situasi demikian menyebabkan perjanjian kerjasama tersebut tidak ada artinya (Kasper and Streit ,1998).

Alur transaksi input-otput kemitraan di Kabupaten Ciamis pendek. Sampai saat ini belum ada pihak lain yang berfungsi sebagai perantara dalam penyaluran input-output tersebut sehingga aliran transaksi langsung dirasakan oleh kedua belah pihak. Mitra di Kabupaten Ciamis menempatkan karyawannya sebagai koordinator lapangan yang tinggal di tengah-tengah petani. Mitra juga merekut beberapa orang dari desa proyek sebagai tenaga pengawas atau mandor yang bertanggungjawab terhadap penyaluran sarana produksi dan pengawasan di lapangan. Hal ini memudahkan komunikasi antara petani dengan mitra. Pada saat penanaman, bibit langsung dibagikan ke tiap-tiap petani dengan jumlah sesuai dengan luas lahan yang tersedia. Petani dapat meminta dan mengambil pupuk atau sarana produksi langsung ke mitra sehingga mitra dapat memonitor petani mana yang rajin memelihara. Demikian pula dengan penjualan hasil tebangan, diharapkan petani menjual langsung ke mitra. Mitra terus berupaya untuk mendapatkan kepercayaan dari petani agar mau terus memelihara tanamannya. Upaya mitra tersebut sesuai dengan pernyataan (Nawir 2011) yaitu komunikasi yang transparan merupakan salah satu cara untuk menjamin pelaksanaan kemitraan.

\section{Analisis Finansial}

Hasil analisis finansial menunjukkan bahwa kemitraan pengelolaan hutan rakyat di Kabupaten Garut dan Ciamis layak secara finansial, tetapi di Kabupaten Tasikmalaya tidak layak (Tabel 5). Nilai NPV di Kabupaten Ciamis jauh lebih tinggi daripada di Kabupaten Garut dan Tasikmalaya karena potensi kayu per hektar di Kabupaten Ciamis yang jauh lebih tinggi daripada di Kabupaten Garut dan Tasikmalaya, dan harga kayu jabon per $\mathrm{m}^{3}$ lebih tinggi daripada kayu albasia.

Kemitraan pengelolaan hutan rakyat di Kabupaten Tasikmalaya tidak mampu memberikan keuntungan finansial sehingga tidak tercipta kinerja yang dapat menjamin terwujudnya keberlanjutan kemitraan pengelolaan hutan rakyat. Kelayakan finansial pada kemitraan pengelolaan hutan rakyat di Kabupaten Tasikmalaya terjadi hanya pada petani hutan rakyat. Kondisi tersebut disebabkan karena potensi kayu yang akan ditebang sangat

Tabel(Table) 5. Analisis finansial kemitraan pengelolaan hutan rakyat di lokasi studi (Financial analysis on partnership of private owned forest managementin area studies)

\begin{tabular}{lccclrrr}
\hline \multicolumn{7}{c}{ Total (Total) } & \multicolumn{5}{c}{ Masing-masing pelaku (Actor) } \\
\hline $\begin{array}{l}\text { Kabupaten } \\
\text { (District) }\end{array}$ & NPV & BCR & IRR & & NPV & BCR & IRR \\
\hline Garut & 251.221 & 1,06 & $14,76 \%$ & Mitra (Partner) & 124.752 & 1,09 & $15,29 \%$ \\
& & & & Petani (Farmer) & 126.469 & 1,05 & $14,44 \%$ \\
Tasikmalaya & -641.503 & \multirow{2}{*}{0.78} & \multirow{2}{6}{, $54 \%$} & Mitra (Partner) & -885.127 & 0,18 & $-21,10 \%$ \\
& & & & Petani (Farmer) & 243.623 & 1,13 & $16,61 \%$ \\
Ciamis & 5.529 .404 & \multirow{2}{*}{1,30} & \multirow{2}{*}{$18,22 \%$} & Mitra (Partner) & 2.166 .497 & 1,20 & $18,22 \%$ \\
& & & & Petani (Farmer) & 3.362 .906 & 1,44 & $26,33 \%$ \\
\hline
\end{tabular}


sedikit (sekitar 35\% dari pohon yang ditanam) dan pertumbuhan diameter yang kecil. Selain itu, pembagian hasil antara petani dan mitra $(75 \%$ dan $15 \%$ ) tidak seimbang dengan kontribusi input kedua pihak (55\% dan $45 \%$ ).

Mitra beranggapan bahwa kegiatan kemitraan dengan memberi bantuan bibit dan pupuk kepada petani sebagai kegiatan CSR (company social responsibility) (Nawir dan Santoso, 2005; Pardede dan Finnahari, 2007). Mitra mempunyai pengalaman, bahwa cukup sulit mengharapkan komitmen dari petani dalam melaksanakan kemitraan. Hal ini karena petani sudah mempunyai pengetahuan tentang informasi harga dan pasar sehingga mempunyai kemampuan negosiasi harga dengan pembeli kayu. Di lain pihak petani menganggap bahwa bantuan bibit dan pupuk pada awal penanaman dari perusahaan tidak begitu berarti dibandingkan biaya keseluruhan yang diperlukan untuk memelihara tanaman sampai penebangan (Race etal., 2009).

\section{E. Kinerja Kemitraan}

Kinerja kemitraan pengelolaan hutan rakyat di lokasi studi cukup beragam yang dipengaruhi oleh kedekatan pihak, kepatuhan terhadap kesepakatan perjanjian, pengawasan dan sanksi pelanggaran kesepakatan, serta proporsi sharing input-output.

Perjanjian kesepakatan kemitraan pengelolaan hutan rakyat di Kabupaten Garut dan Kabupaten Tasikmalaya dibuat dengan perjanjian formal, akan tetapi terjadi ketidakseimbangan antara hak dan kewajiban kedua belah pihak. Petani di Kabupaten Garut dapat mematuhi perjanjian kerjasama tersebut karena telah terjalin hubungan harmonis antara petani dengan mitranya. Petani mempunyai kesan yang baik terhadap mitra. Hal tersebut merupakan suatu keuntungan bagi mitra untuk melakukan pengawasan terhadap perjanjian kesepakatan. Namun demikian, kondisi tersebut berpotensi juga untuk berlakunya ketidaksepadanan informasi (asymmetric impormation), khususnya mengenai penghitungan kubikasi dan kualitas kayu yang dipanen. Walaupun potensi kayu hasil kemitraan relatif rendah, kemitraan di Kabupaten Garut mempunyai kelayakan secara finansial. Hal ini karena sharing input-output yang seimbang dan berkurangnya biaya transaksi.

Kinerja kelembagaan kemitraan di Kabupaten Tasikmalaya dapat dikatakan tidak berhasil. Hal ini ditunjukkan dengan hasil analisis finansial yang mempunyai NPV $<0, \mathrm{BCR}<1$, dan IRR
$<13 \%$. Tidak berhasilnya kemitraan di lokasi ini karena hubungan kedua belah pihak tidak begitu dekat yang disebabkan transaksi input-output yang tidak langsung. Selain itu, terdapat masalah ketidakpatuhan terhadap kesepakatan, terdapat potensi moral hazard, kurangnya pengawasan terhadap pelanggaran, serta tidak adanya sanksi pelanggaran dari kedua belah pihak walaupun tercantum pada perjanjian kesepakatan. Perjanjian kesepakatan pada akhirnya tidak bermakna sebagai pengawal kemitraan, dan karena biaya keagenan semakin tinggi maka kemitraan cenderung akan gagal.

Kemitraan pengelolaan hutan rakyat di Kabupaten Ciamis, sejauh ini, berjalan baik. Perjanjian kesepakatan, walaupun dibuat dalam bentuk tidak formal, masih dapat dilaksanakan oleh kedua belah pihak. Pihak mitra sangat berkepentingan terhadap keberhasilan penanaman karena mereka telah mengeluarkan investasi yang besar. Selain itu, petani mempunyai harapan mendapatkan keuntungan dengan melakukan kemitraan penanaman. Mitra mempekerjakan tenaga sebagai koordinator lapangan yang tinggal disekitar lokasi penanaman serta tenaga pengawas dari lingkungan petani sehingga komunikasi dan pengawasan kedua pihak dapat berjalan. Namun demikian, petani masih mempunyai keraguan terhadap jaminan pasar, sehingga mitra harus memberikan kepercayaan yang tinggi terhadap petani.

\section{KESIMPULAN}

\section{A. Kesimpulan}

1. Karakteristik kemitraan pengelolaan hutan rakyat di lokasi studi bervariasi yang ditunjukkan dengan perbedaan hubungan kedekatan mitra terhadap dan upaya penegakan terhadap kesepakatan perjanjian. Hubungan petani dan mitra di Kabupaten Garut lebih dekat daripada di kabupaten Tasikmalaya, sedangkan mitra di Kabupaten Ciamis masih dalam tahap pendekatan dengan petani.

2. Potensi kayu hasil kemitraan di lokasi studi sangat rendah dengan rerata diameter tanaman $4 \mathrm{~cm}$. Keberhasilan tanaman di Kabupaten Tasikmalaya paling rendah (36\%) daripada di Kabupaten Garut dan Ciamis yang berturut-turut mencapai $65 \%$ dan $76 \%$. Hal ini karena kurangnya pemeliharaan di Kabupaten Tasikmalaya serta adanya serangan hama penyakit. 
3. Alur transaksi input-output pada kemitraan di Kabupaten Tasikmalaya lebih panjang daripada di Kabupaten Garut dan Tasikmalaya karena terdapat beberapa pihak yang terlibat dalam transaksi input-output. Panjangnya alur transaksi tersebut menyebabkan tingginya biaya transaksi.

4. Kemitraan pengelolaan hutan rakyat di Kabupaten Garut $(\mathrm{NPV}=251.221, \mathrm{BCR}=1,06$, $\mathrm{IRR}=14,76 \%)$ dan Ciamis (NPV $=5.529 .404$, $\mathrm{BCR}=1,30$, dan $\mathrm{IRR}=18,22 \%$ ) dinyatakan layak secara finansial. Sementara kemitraan di Kabupaten Tasikmalaya tidak layak secara finansial karena NPV=-641.503, BCR=0,78, dan IRR $=6,54 \%$.

5. Kinerja kemitraan pengelolaan hutan rakyat di lokasi studi dipengaruhi oleh terdapatnya masalah keagenan (agency problems), yaitu yang menyangkut pemindahan hak kepemilikan, ketidak sepadanan informasi, serta munculnya biaya transaksi. Biaya keagenan yang tinggi menyebabkan gagalnya kemitraan.

\section{B. Saran}

Beberapa temuan yang perlu dipertimbangkan oleh pemerintah dalam melakukan program kemitraan, yaitu:

1. Badan Pelaksana Penyuluhan perlu melakukan penyiapan petani sebagai calon peserta kemitraan dalam hal pemahaman masalah keagenan yaitu: hak dan kewajiban, kepatuhan terhadap kesepakatan, dan keseimbangan informasi.

2. Terlaksananya kemitraan pengelolaan hutan rakyat memerlukan kepedulian yang tinggi dari pengusaha terhadap petani hutan rakyat. Untuk itu pemerintah pusat (melalui Balai Pemantauan Pemanfaatan Hutan Produksi) dan pemerintah kabupaten (melalui Dinas Kehutanan) perlu melakukan pendekatan dan pemahaman kepada pengusaha sebagai calon mitra tentang pentingnya menjalin hubungan yang baik dan meningkatkan kepedulian kepada kemandirian petani.

\section{DAFTAR PUSTAKA}

Achmad, B., D.Diniyati, E.Fauziah. 2010. Potensi dan peran Pesantren sebagai Lembaga Pelaksana Kegiatan Rehabilitasi Hutan dan Lahan (RHL). J. Penelitian Sosial dan Ekonomi Kehutanan 7(1):41-54.
Departemen Kehutanan (Dephut). 2006. Rencana Pembangunan Jangka Panjang Kehutanan tahun 2006-2025. Jakarta. Departemen Kehutanan.

Direktorat Jenderal BPK. 2009. Insentif dan Disinsentif Tata Usaha Kayu Hutan Rakyat. Presentasi disampaikan pada Pekan Raya Hutan dan Masyarakat, Yogyakarta, 20 September 2009.

Effendi, R. 2008. Kajian Tata Niaga kayu rakyat di Jawa Bagian Barat. Info Sosial Ekonomi 8(2): 113-124.

Frankel, R., J.S.Whipple, D.J. Frayer. 1996. Formal versus Informal Contracts: Achieving Alliance success. International Journal of Physical Distribution \& Logistics Management 26 3): 4763.

Gittinger J.P. 1982. Economic analysis of agricultural projects. Second Edition. The Economic Development Institute of the World Bank. The Johns Hopkins University Press: Baltimore and London.

Hakim, I. Indartik, E.Y. Suryandari. 2009. Analisis Tataniaga dan Pasar Kayu Albasia di Kabupaten Wonosobo dan Kabupaten Temanggung Jawa Tengah. J. Penelitian Sosial dan Ekonomi Kehutanan 6(2):99-115.

Hardjanto. 2001. Kontribusi Hutan Rakyat terhadap Pendapatan Rumah Tangga di sub DAS Cimanuk Hulu. J. Manajemen Hutan Tropika 7(2): 4761.

Kasper W., M.E.Streit. 1998. Institutional economics: Social Order and Public Policy. Edward Elgar Publishing Limited, UK.

Key N., D. Runsten. 1999. Contract Farming, Smallholders, and Rural Development in Latin America: The Organization of Agroprocessing iirms and the Scale of Outgrower Production. World Development 27(2):381-401.

Krejcie, R.V., D.W. Morgan. 1970. Determining Sample Size for Reasearch Activities. Educational and Psychological Measurement30:607-610.

Krisnawati, H., M. Kallio, M. Kanninen. 2011. Anthocephalus cadamba Miq.: Ekologi, Silvikultur dan Produktivitas. Bogor. Center for International Forestry Research.

Kusumedi, P., A.A.Nawir. 2010. Analis Pengelolaan dan Hutan Rakyat Kemitraan di Kabupaten Bulukumba, Provinsi Sulawesi Selatan. J. Penelitian Sosial dan Ekonomi Kehutanan 7 (1) : $1-21$

Mayers, J. 2000. Company-Community Forestry Partnerships: a Growing Phenomenon. Unasylva 200(51):33-41. 
Miyata S., M.Minot, D.Hu. 2009. Impact of Contract Farming on income: Linking Small farmers, packers, and supermarkets in China. World Development 37(11):1781-1790.

Nawir AA. 2011. Satu Dasawarsa Perjalanan Kemitraan Masyarakat-Perusahaan HTI di Indonesia : Studi kasus Finnantara Intiga, Sanggau, Kalimantan Barat. J. Kehutanan Masyarakat 3 (1) : 6-31.

Nawir A.A., L.Santoso. 2005. Mutually beneficial company-community partnerships in plantation development: emerging lessons from Indonesia. International Forestry Review 7 (3).

Orwa C., A. Mutua, R. Kindt, R. Jamnadass, A. Simons. 2009. Agroforestree database: a tree reference and selection guide version 4.0. http://www. worldagroforestry.org/treedb2/. Akses tanggal 6 Februari 2013).

Pardede P.J., S. Finnahari. 2007. Pola Kemitraan dalam Praktek Tanggungjawab Sosial Perusahaan: Studi Kasus Program Community Develop- ment PT. Toba Pulp Lestari TBk, di Kabupaten Samosir. J. Kebijakan dan Administrasi Publik 11(2):203-31.

Prihadi N., D. Darusman, B. Nugroho, N. Wijayanto. 2010. Kemitraan Industri Pengolahan Kayu bersama Rakyat untuk Membangun Hutan di Pulau Jawa. J. Penelitian Hutan Tanaman 7 (3) : 121-129.

Purwanto E.A., D.R. Sulistyastuti. 2011. Metode Penelitian Kuantitatif untuk Administrasi Publik dan Masalah-masalah Sosial. Yogyakarta. Penerbit Gava Media.

Race D et al. 2009. Partnerships for Involving SmallScale Growers in Commercial Forestry: Lessons from Australia and Indonesia. International Forestry Review 11(1).

Smith L.E.D., M. Stockbridge, H.R. Lohano. 1999. Facilitating the Provision of Farm Credit: The Role of Interlocking Transactions between Traders and Zamindars in Crop Marketing Systems in Sindh. World Development 27(2):403-418. 